\title{
Genetic legacy of cultures indigenous to the Northeast Asian coast in mitochondrial genomes of nearly extinct maritime tribes
}

\author{
Stanislav V. Dryomov', Elena B. Starikovskaya', Azhar M. Nazhmidenova', Igor V. Morozov'²,3 and
} Rem I. Sukernik ${ }^{1 *}$ (D)

\begin{abstract}
Background: We have described the diversity of complete mtDNA sequences from 'relic' groups of the Russian Far East, primarily the Nivkhi (who speak a language isolate with no clear relatedness to any others) and Oroki of Sakhalin, as well as the sedentary Koryak from Kamchatka and the Udegey of Primorye. Previous studies have shown that most of their traditional territory was dramatically reshaped by the expansion of Tungusic-speaking groups.

Results: Overall, 285 complete mitochondrial sequences were selected for phylogenetic analyses of published, revised and new mitogenomes. To highlight the likely role of Neolithic expansions in shaping the phylogeographical landscape of the Russian Far East, we focus on the major East Eurasian maternal lineages (Y1a, G1b, D4m2, D4e5, M7a2, and N9b) that are restricted to the coastal area. To obtain more insight into autochthonous populations, we removed from the phylogeographic analysis the G2a, G3a2, M8a1, M9a1, and C4b1 lineages, also found within our samples, likely resulting from admixture between the expanding proto-Tungus and the indigenous Paleoasiatic groups with whom they assimilated. Phylogenetic analysis reveals that unlike the relatively diverse lineage spectrum observed in the Amur estuary and northwestern Sakhalin, the present-day subpopulation on the northeastern coast of the island is relatively homogenous: a sole Y1a sublineage, conspicuous for its nodal mutation at m.16189 T > C!, includes different haplotypes. Sharing of the Y1a-m.16189 T > C! sublineages and haplotypes among the Nivkhi, Ulchi and sedentary Koryak is also evident. Aside from $\mathrm{Y} 1 \mathrm{a}$, the entire tree approach expands our understanding of the evolutionary history of haplogroups G1, D4m, N9b, and M7a2. Specifically, we identified the novel haplogroup N9b1 in Primorye, which implies a link between a component of the Udegey ancestry and the Hokkaido Jomon.
\end{abstract}

\footnotetext{
* Correspondence: sukernik@mcb.nsc.ru

'Laboratory of Human Molecular Genetics, Institute of Molecular and Cellular Biology, SBRAS, Novosibirsk, Russian Federation

Full list of author information is available at the end of the article
}

(C) The Author(s). 2020 Open Access This article is licensed under a Creative Commons Attribution 4.0 International License, which permits use, sharing, adaptation, distribution and reproduction in any medium or format, as long as you give appropriate credit to the original author(s) and the source, provide a link to the Creative Commons licence, and indicate if changes were made. The images or other third party material in this article are included in the article's Creative Commons licence, unless indicated otherwise in a credit line to the material. If material is not included in the article's Creative Commons licence and your intended use is not permitted by statutory regulation or exceeds the permitted use, you will need to obtain permission directly from the copyright holder. To view a copy of this licence, visit http://creativecommons.org/licenses/by/4.0/. The Creative Commons Public Domain Dedication waiver (http://creativecommons.org/publicdomain/zero/1.0/) applies to the data made available in this article, unless otherwise stated in a credit line to the data. 


\begin{abstract}
(Continued from previous page)
Conclusions: Through a comprehensive dataset of mitochondrial genomes retained in autochthonous populations along the coast between Primorye and the Bering Strait, we considerably extended the sequence diversity of these populations to provide new features based on the number and timing of founding lineages. We emphasize the value of integrating genealogical information with genetic data for reconstructing the population history of indigenous groups dramatically impacted by twentieth century resettlement and social upheavals.
\end{abstract}

Keywords: Mitochondrial genomes, mtDNA lineages, Russian Far East, Native people, Phylogeography

\section{Background}

"Northeastern Paleoasiatic people" refers to a heterogeneous set of populations in the Russian Far East and eastern Siberia, including the Nivkhi in the Lower Amur region and Sakhalin, the Yukaghir, and ChukotkoKamchatkan peoples. The Chukotko-Kamchatkan peoples are thought by many investigators to have had a special relationship with the ancient inhabitants of a vast portion of Northeast Asia before this territory was dramatically reshaped by the expansion of Tungusic-speaking groups [1-3]. The contours of Northeastern Paleoasiatic ethnogenesis become archeologically visible at the onset of the Neolithic era (beginning in the late Pleistocene in the Russian Far East but regionally varying, with early Neolithic onset in Sakhalin at $~ 7000-5000$ BC) [4]. In this period, the predominant tundra belt between the Arctic Ocean and Anadyr River and the taiga zone between the Anadyr and Koryak Mountains were characterized by nomadic hunters mainly pursuing wild reindeer, supplemented by some inland fishing and plant gathering. Coastal areas extending from Chukotka remained largely uninhabited until the late Neolithic [3]. The core of this model is represented by diverse sedentary Koryak groups occupying the northern coasts of the Okhotsk Sea. The Koryak prehistory reflects a long stage of fishing and hunting cultures of the Neolithic and post-Neolithic periods, followed by Tokarev (seventh c. BC to second c. AD) and subsequent Old Koryak cultures (formed in the early 1st millennium AD) that introduced specialized marine animal hunting. The Old Koryak cultures extended along the western coasts of the Sea of Okhotsk to reach Sakhalin Island and played a key role in the formation of "Okhotsk culture", a contested collective designation for foragerfisher cultures with strong marine orientations across Sakhalin, Hokkaido, and the Kurile Islands in the mid-1st to early-2nd centuries AD [5-7].

\section{The Nivkhi}

The traditional area of Nivkhi inhabitance consists of two main territorial subdivisions - the mainland subgroup dispersed up to $100 \mathrm{~km}$ in the lower course of the Amur River area and a coastal subgroup living mainly along the northwestern and northeastern coasts of Sakhalin Island.
In traditional times, the Nivkhi were sea mammal hunters of the Lower Amur/Southern Okhotsk region and numbered in the several thousands. Despite territorial and political claims to Sakhalin from the Mongol and Manchu Empires, the Nivkhi remained the numerically predominant aboriginal people until the modern colonial period, when influxes of Russians from the north and Japanese from the south reduced them to minority status.

The first Russians to write about the Nivkhi in the mid-seventeenth century called them "Gilyak" (a Tungus exonym), by which they would be referred until 1930 [8]. Records from the second half of the nineteenth century show a decline in the population size, dropping to 3270 [9]. In 2002, the Nivkhi community increased to 4902, with roughly half living on Sakhalin and half on the mainland. The Nivkhi may never have been widespread on the mainland beyond the coastal belt and Amur estuary, in contrast to Sakhalin Island, which was probably entirely inhabited by ancestors of the Nivkhi before the colonization of its southern regions by the Ainu from Hokkaido during the eleventh century. The Nivkhi language is a true isolate, a linguistic lineage outside the world's major language families, with no demonstrable genealogical relation to either neighboring or geographically distant languages [10]. Although preHolocene archeology is documented from central and southern Sakhalin, the earliest archeological dates for Northern Sakhalin are Neolithic [11].

\section{The Koryak}

Prior to the Tungus's appearance in the 15th and 16th centuries, the Sea of Okhotsk was inhabited by the coastal Koryak as far as the Nivkhi ethnic border on the Uda River. The ethnic composition of the coastal Koryak comprised dialectally and culturally diverse groups of sedentary river fishers and (to a lesser extent) sea hunters, who gradually assimilated and converged into a broader generic group [12-17]. As a result of the northeastern spread of the Tungusic people, a large segment of the Koryak population was assimilated, and the coastal Koryak territory became greatly reduced, effectively ending the Old Koryak culture there [12]. By the turn of the twentieth century, Reindeer Koryak, close enough to Chukchi, 
inhabited the forest tundra zone of northwestern Kamchatka and the Penzhina River basin and the northeastern part of the Kamchatka mainland [12, 14].

\section{The Udegey}

The ethnonym Ude (Udi, Udiha) was originally mentioned during the fifth century in reference to a coastal tribe on the Sea of Japan. The early history of the Udegey is thought to be similar to that of other members of the Amur complex (closely related Tungusic-speaking sedentary populations mostly inhabiting the Lower Amur region), as they are presumed descendants of both fishing and hunting groups who inhabited the area since Neolithic times. All the variants of basic Udegey cultures, including one primarily based on sedentary river fishing among lowland groups, one based on forest hunting among mountain groups, and another based on sea mammal hunting among coastal groups, point to a cultural origin common to other Amur groups such as the Ulchi but separate from their Tungus and Manchu neighbors [18]. Hence, the Udegey lineage structures are very complex, with most lineage segments ultimately claiming descent from lineages of other ethnic groups. One reason for the interlineage and interethnic fusion is, as among all other Amur groups, the importance of the exogamous alliances among lineages, which frequently cut across ethnolinguistic boundaries [3]. At the present time, the Udegey number no more than 1000 people. The Udegey groups' original language belongs to the Tungusic family. However, most of them have already been assimilated into the majority of surrounding Russian speakers.

\section{The Oroki (Ulta)}

The ancestors of today's Ulta were a group of Tungusinfluenced Ulchi who migrated to central Sakhalin with

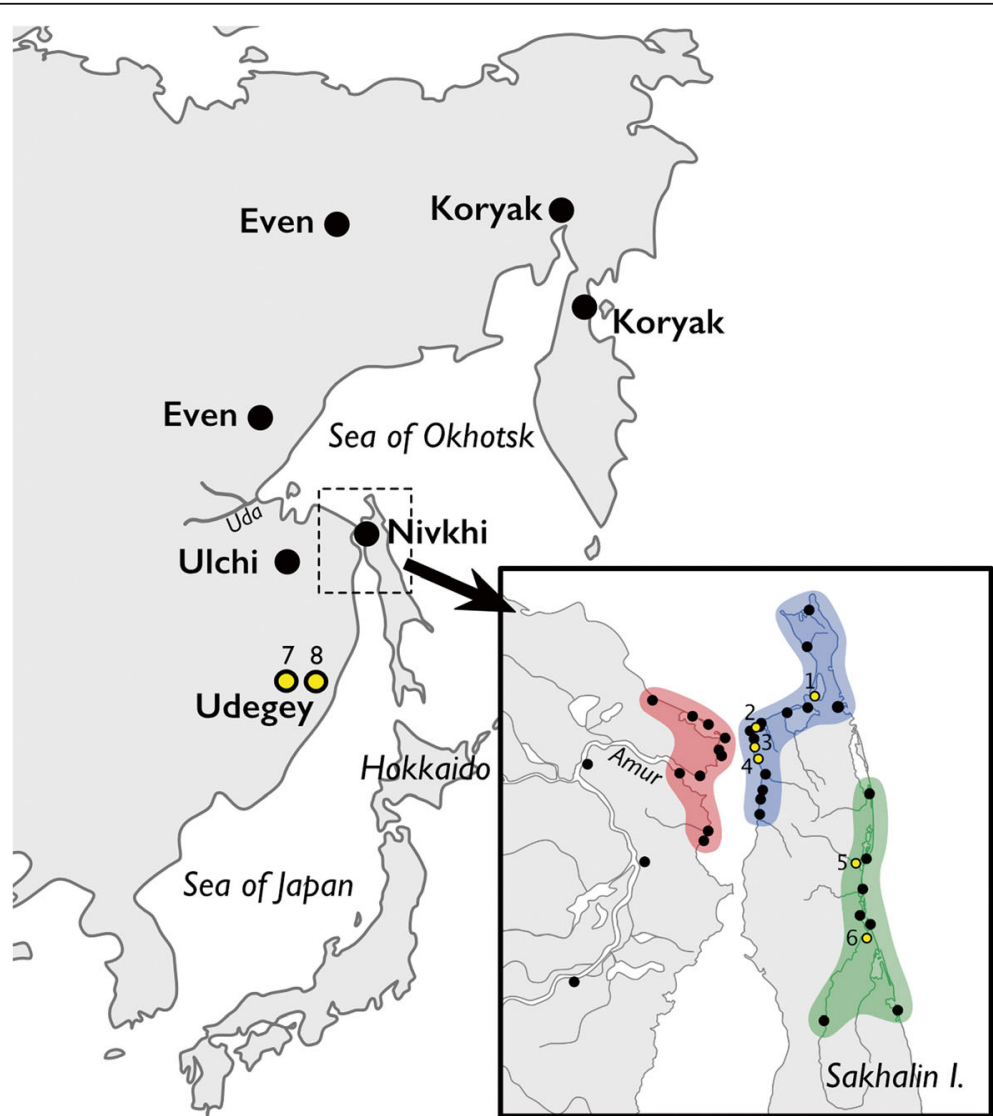

Fig. 1 Map of the Russian Far East and adjacent part of the North Pacific, showing mtDNA sampling locations. The enclosed inlet shows how birthplaces of the maternal grandmothers of study participants relate to the documented geographic distribution of distinct Nivkhi dialects. Yellow circles mark the locations of sampling expeditions: 1-Nekrasovka, 2-Rybnovsk, 3-Rybnoye, 4-Lupolovo, 5-Nogliki, 6-Val, 7-Gvasiugi, and 8-Agzu. Black dots denote locations of the abandoned settlements, with the birthplaces of donors highlighted in red on the mainland, blue on northwestern Sakhalin, and green on the eastern coast of the island. Additional information on sampling collection was reported in previous works [20-22]. Many Nivkhi settlements, mostly located in the Amur estuary, were susceptible to flooding and sometimes completely wiped out, as in the Amur flood of 1968. In the process of twentieth century centralization, the Nivkhi and Oroki were forcibly displaced from their more widely distributed settlements into more consolidated locations [8]. This map was made using Affinity Designer version 1.7.3 (https://affinity.serif.com/designer). Data were obtained from OpenStreetMap (https:/www.openstreetmap.org/) 
their reindeer during approximately the sixteenth century. Present-day Oroki are among the smallest and most demographically precarious native tribes in Siberia. In 2002, their population size was $\sim 200[8,19]$. They speak a language belonging to the southern subdivision of the Tungusic language family. Notably, many of the Oroki (as well as Nivkhi villages located in the Amur estuary) were susceptible to the impacts of flooding and sometimes completely wiped out, as in the Amur flood of 1968. Hence, we used the birthplace of their maternal grandmothers from abandoned settlements as the location identifier for each complete mitochondrial DNA (mtDNA) sequence, thereby providing information about its location prior to the birth year of the sample donor.

To fill the phylogeographic gap between Kamchatka and Sakhalin toward the coast of the Sea of Japan, $56 \mathrm{mtDNA}$ samples from the northwestern Sakhalin and the Amur estuary are revised and synthesized with 52 new blood samples (46 Nivkhi and 6 Oroki) drawn in fall 2016 in the Nogliki and Val settlements, Nogliki District, Sakhalin Region, Russian Federation (Fig. 1). Samples from 93 Nivkhi and Oroki were subjected to complete sequencing: 52 from the current study and 41 previously published. In addition, 27 samples of sedentary Koryak were chosen from a much larger set of previously collected Koryak samples not yet examined at the entire mtDNA genome level [23] and were completely sequenced. Finally, mtDNA from 46 Udegey from our earlier studies in the SikhoteAlin Mountains in the lower and southern portions of the Amur Basin [20-22, 24] were revised and supplemented by 13 new samples drawn in March 2018 from the village of Agzu, Terney District, Primorsky Krai (Fig. 1).

\section{Results}

The total data set $(n=285)$ was assigned mainly to lineages Y1a, G1b, D4m, D4e5, N9b, and M7a2 (Additional file 1: Table S1). To focus our phylogenetic analyses, we removed G2a, G3a2, M8a1, M9a1, and C4b1, representing likely admixture among protoTungus peoples expanding from Manchuria. The derived haplotypes within the main trees in Figures S1-S6 (Additional files 2, 3, 4, 5, 6 and 7) allow for inferences pertaining to the genetic origin of the populations and their relationships with each other. The age estimates, coalescence time, and variance computed from the roots and younger nodes are given in Table 1.

\section{Haplogroup Y1a}

mtDNA haplogroup Y (a descendant of haplogroup N9) is proposed to indicate matrilineal genetic continuity between late Pleistocene hunter-gatherer groups and present-day populations in the Far East [22, 25-29]. Within Siberia, the majority of contemporary Y1 carriers
Table 1 Age estimates for haplogroups Y1a, G1b, D4e5, D4m, and $\mathrm{N9b}$ and their major subhaplogroups

\begin{tabular}{lll}
\hline Haplogroup & $\mathrm{N}$ & ML age $(95 \% \mathrm{Cl}), \mathrm{kya}$ \\
\hline Y1 & 116 & $15.47(9.09 ; 22.90)$ \\
>Y1a & 101 & $10.56(6.35 ; 15.35)$ \\
> > Y1a1 & 10 & $6.48(3.22 ; 10.26)$ \\
> > Y1a-16189! & 89 & $7.51(4.58 ; 10.79)$ \\
G1b & 61 & $11.35(6.27 ; 17.08)$ \\
>G1b1 & 13 & $6.96(3.41 ; 10.82)$ \\
>G1b-16129! & 48 & $9.09(5.06 ; 13.32)$ \\
D4e5 & 12 & $11.76(5.56 ; 18.52)$ \\
>D4e5a & 5 & $4.90(1.72 ; 8.60)$ \\
>D4e5b & 7 & $6.96(2.61 ; 12.09)$ \\
D4m & 24 & $17.50(9.28 ; 27.06)$ \\
>D4m2 & 21 & $8.52(4.46 ; 13.56)$ \\
> > D4m2a & 19 & $6.25(3.29 ; 9.66)$ \\
>> > D4m2a1 & 5 & $2.65(0.80 ; 4.80)$ \\
>D4m1 & 3 & $3.98(1.14 ; 7.18)$ \\
N9b & 44 & $18.31(12.58 ; 24.79)$ \\
> N9b1 & 16 & $15.47(9.09 ; 22.90)$ \\
> N9b4 & 18 & $10.56(6.35 ; 15.35)$ \\
M7a2 & 17 & $15.60(9.74 ; 22.56)$ \\
> M7a2a & 16 & $14.04(8.89 ; 19.49)$ \\
> > M7a2a3 & 10 & $6.48(3.10 ; 10.21)$ \\
>> > M7a2a3a & $3.11(0.90 ; 5.57)$ \\
\hline & &
\end{tabular}

cluster into Y1a marked by the coding change m.7933A > $\mathrm{G}$ (aged $10.6 \mathrm{kya}$ ), whereas Y1b and Y1c are confined to continental China, Japan, and Korea (Additional file 2: Figure S1). Accordingly, two offshoots arose from the Y1a founding haplotype for this haplogroup. On one side, the newly refined Y1a1 haplotype defined by $\mathrm{m} .12732 \mathrm{~T}>\mathrm{C}$ is well represented in Tungusic-speaking groups (e.g., Evenki, Udegey), while the other side harbors a back mutation at $\mathrm{np}$ m.16189 $\mathrm{T}>\mathrm{C}$ relative to the Reconstructed Sapiens Reference Sequence (RSRS). Sequence diversification within the Y1a-m.16189 T > C! haplogroup is characteristic (at most) of the Nivkhi from Sakhalin. The updated network analysis includes $10 \mathrm{Y} 1 \mathrm{a} 2$ sequences defined by m.12397A>G, of which 7 are new from the coastal Koryak.

\section{Haplogroup G1b}

The newly reconstructed tree encompassing 61 mitogenomes (36 new and 25 published) illustrates the immediate split of G1b that created two offshoots. One is G1b1, defined by m.16207A $>\mathrm{G}$, and the other is G1bm.16129G > A! (Additional file 3: Figure S2). Whereas the G1b-m.16129G > A! cluster is exceptionally diverse, thus revealing the origins and relationships of the 
various cultures, G1b1 is much less prominent, being limited to a few sublineages. Notably, sequence data positive for m.16207A > G evidently shared an mtDNA haplotype of the G1b1 haplogroup among the Nivkhi, Ulchi, Coastal Koryak, and Itelmen [21-23].

\section{Haplogroup D4m2}

The updated haplogroup D4m2 (D8 in [30]) is presented in Figure S3 (Additional file 4). The D4m2a sequences harbored by the Nivkhi are shown along with those from the Yukaghir, Evenki, Even, Tuvan, Buryat, Tubalar, and Tuvan from previous studies [22, 30-32]. Notably, the Nivkhi are the only bearers of $\mathrm{D} 4 \mathrm{~m} 2 \mathrm{a}$ root haplotypes, while the Even, Evenki, and Yukaghir are grouped within the D4m2a1 subcluster.

\section{Haplogroups D4e5}

We discovered D4e5b in 5 of 6 Oroki samples subjected to complete mtDNA sequencing (Additional file 5: Figure S4). Although an identical D4e5b sequence was previously identified in a sole Even individual (Nlk24) from a village on the Maya River, Okhotsk region (FJ858882), the HVS-I database indicates the major presence of $\mathrm{D} 4 \mathrm{e} 5 \mathrm{~b}$ markers (m.16274G > A and m.16291C > T) among the Oroki from Sakhalin [33]. It appears that the most represented sublineage of D4e5b arose in the Amur basin $7.0 \mathrm{kya}$, whereas the age of the entire D4e5 haplogroup is 11.8 kya (Table 1), suggesting its ancestral homeland in interior Siberia and a subsequent split into two subclusters, D4e5a and D4e5b.

\section{Haplogroups N9b and M7a2}

The Udegey group is found to consist of two mtDNA haplogroups: N9b and M7a2 (see Table 1 and Additional file 6: Figures S5 and Additional file 7: Figure S6). Aside from the Udegey originating in the villages of Gvasygi and Agzu in the Sikhote-Alin/Primorye region, we sampled the Udegey individuals who married into Ulchi and Nivkhi families dispersed along the reaches of the Lower Amur [22]. Haplogroup N9b is represented mainly by lineages of four major subhaplogroups: N9b1, N9b2, N9b3, and N9b4 [34-36]. We identified a novel N9b1 mitogenome (MH807371) in one individual from Primorye (Agzu), hence expanding the established geographical scope of the N9b1 haplogroup and disclosing a link between a component of the Udegey ancestry and the Hokkaido Jomon from Japan [36-38]. The second prevalent haplogroup is M7a2a3a, which was detected in 8/46 (17.4\%) of the Udegey samples (Table 1, Additional file 7: Figure S6). The Udegey, as well as the Hokkaido Jomon, lack subhaplogroup M7a1, which is the predominant subhaplogroup in modern Japanese and Korean populations ([39] and ref. therein).

\section{Discussion}

The phylogeographic dissection of matrilineal pools presented here revealed a wide range of distinct mtDNA lineages, some of which chronologically coincide with archeological phases of the Neolithic and could reveal matrilineal continuity between present-day populations and early Holocene forebears in the same region. It is not surprising to see considerable sharing of Y1a-m.16189 T > C! sublineages and haplotypes between the Nivkhi and Ulchi samples, given ethnographic evidence for mainlandSakhalin interaction over the past several centuries. Notably, the Ulchi territory coincided with the meeting point of two trade routes, i.e., one via Lake Kizi and short portages leading to rivers flowing to the Tatar Strait and the other along the Amur to its estuary and to Sakhalin Island. Combined with their social position as silk trade middlemen officially sanctioned by the Qing administration, this was without a doubt a major factor leading to the formation of the Ulchi as a separate ethnic identity [3].

New complete sequences have refined the ancestral G1b type and hence implied genetic continuity between the Lower Amur and Kamchatka. The Lower Amur might have functioned as an incubator and ancestral homeland of the G1b root in the early Holocene before the split and subsequent spread of G1b-m.16129G > A! into higher latitudes. This conjecture is supported by the recent detection of ancient G1b in Duvanni Yar (Kolyma1), dated to $\sim 9.8 \mathrm{kya}$, as well as at the Ol'skaya site, dated to $\sim 3.0 \mathrm{kya}$, from the Magadan area, Chukotka [40]. Interestingly, mtDNA data from previously published studies on Russian old settlers in the Kolyma-Indigirka-Anadyr region, which relates to Yukaghir history, reveal high frequencies of G1b-m.16129G > A! [22, 30, 41, 42].

Despite the fact that the D4m2 haplogroup is scattered throughout a vast territory stretching over northern China and Mongolia, the Russian Far East and North Siberia, its frequency and diversity across the entire area are low, with the Lower Amur and Primorye being exceptions. Important caveats include single nucleotide polymorphism (SNP) sequences related to $\mathrm{D} 4 \mathrm{~m}$ in Neolithic remains $(5726-5622 \mathrm{cal} \mathrm{BC})$ from the Devil's Gate cave sites in Primorye [40, 43], thus indicating longstanding genetic succession in this region during the Holocene.

From the phylogenetic network (Additional file 6: Figures S5 and Additional file 7: Figure S6), it is possible to infer that the Udegey represent admixture of southern Siberian populations and the northern Jomon people. Interestingly, Wang et al., 2020 [44] reported data on Jomon hunter-gatherers from Japan who harbored one of the earliest splitting branches of the East Eurasian variation and showed an affinity among the Jomon, the Amur River Basin, ancient Taiwan, and Austronesian speakers, as expected for their ancestries if they all had 
contributions resulting from late Pleistocene coastal route migration to East Asia. Taken together, these mtDNA findings demonstrate strong genetic overlap between the mitogenome pool of modern autochthonous populations and ancient groups of the Russian Far East.

\section{Conclusion}

Here, we extended the survey of major mitochondrial lineages dispersed across the Russian Far East. Several components may be delineated in this regard. The first component traces back to East Eurasian hunter-gatherers and represents lineages belonging to subdivisions of haplogroups N9b and M7a2. The second is well represented by Y1a and G1b and points to the Lower Amur as the ancestral homeland for this and other haplogroups. The third comprises D4e5, which establishes an association between the Oroki and interior eastern Eurasian populations. Last, rare D4m2a mtDNA exhibited by modern Siberians may have roots in Primorye, at the eastern edge of the continent, rather than a South-Central Siberian source. The data obtained have provided new insights into long-standing questions pertinent to the nature and timing of human colonization of Northeast Asia.

\section{Methods}

\section{mtDNA genome data analysis}

Genomic DNA was extracted from blood buffy coats using standard procedures. The complete sequencing procedure for modern samples entailed PCR amplification of 2 overlapping mtDNA templates that were sequenced with an Illumina HiSeq 2000. Short reads were mapped using bwa version 0.6.1 [45]. All mtDNA genome consensus sequences were called using Unipro UGENE version 1.21 software [46]. We embedded modern and ancient mtDNA genomes in the existing mitochondrial tree of PhyloTree using mtPhyl version 5.003 [47]. mtPhyl follows the hierarchical structure of the tree up to the most derived SNP shared with an existing sequence haplotype. Variants were scored relative to the RSRS [48], with common indels and mutation hotspots at nucleotide positions $\mathrm{m} .309 .1 \mathrm{C}(\mathrm{C})$ and $\mathrm{m} .315 .1 \mathrm{C}$ and $\mathrm{AC}$ indels at m.515m.522, m.16182A $>$ C, m.16183A $>$ C, m.16194A $>$ C, and m.16519 $\mathrm{T}>\mathrm{N}$ being excluded [49]. The haplogroup affiliations reported in this analysis correspond to the current nomenclature of mtDNA in agreement with the latest release of PhyloTree-Build 17 [49].

BEAST version 1.10.1 was used to calculate maximum likelihood (ML) estimates for complete Y1a, G1b, D4m, D4e5, M7a2 and N9b sequences with a log-normal relaxed molecular clock (uncorrelated), using ancient samples as calibration tips [50, 51]. Mutational distances were converted into years using the substitution rate for the entire molecule of $2.67 \times 10^{-8}$ substitutions per site per year [51]. The general time-reversible sequence substitution model with a fixed fraction of invariable sites and gamma-distributed rates $(G T R+I+G)$ was used because this model had the best fit to our data according to jModelTest version 2.1.4 [52]. Using the Markov chain Monte Carlo (MCMC) approach, 50, 000,000 iterations were performed, with samples taken every 1000 steps. The initial $10 \%$ of iterations were considered burn-in and discarded. Inspection of posterior samples ensured sufficient sampling and was used to check for convergence to the stationary distribution.

\section{Supplementary information}

Supplementary information accompanies this paper at https://doi.org/10. 1186/s12862-020-01652-1.

Additional file 1 : Table S1. List of mitogenome sequences included in Figures S1-S6.

Additional file $\mathbf{2}$ : Figure S1. Phylogenetic tree of haplogroup $\mathrm{Y} 1 \mathrm{a}$. Additional file $\mathbf{3}$ : Figure S2. Phylogenetic tree of haplogroup G1b. Additional file 4 : Figure S3. Phylogenetic tree of haplogroup D4m. Additional file 5 : Figure S4. Phylogenetic tree of haplogroup D4e5. Additional file 6 : Figure S5. Phylogenetic tree of haplogroup N9b. Additional file 7 : Figure S6. Phylogenetic tree of haplogroup M7a2.

\section{Abbreviations}

mtDNA: Mitochondrial DNA; Mitogenome: Mitochondrial genome; Cal BC: Radiocarbon-calibrated date Before Christ; Kya: Thousand years ago; Hg: Haplogroup; ML: Maximum likelihood; HVS-I: Hypervariable Segment I; RSRS: Reconstructed Sapiens Reference Sequence; PCR: Polymerase chain reaction; MCMC: Markov chain Monte Carlo

\section{Acknowledgments}

We are grateful to all native people who generously participated in this and related studies. We are indebted to Alexander M.W. Kim for his intellectual contribution. Special thanks to Anatoly P. Derevianko for his assistance in organizing the fieldwork to Sakhalin and Primorye and Andrei V. Tabarev for his interest and discussion. The help of Andre M. Sukernik in editing the final draft of the manuscript is gratefully acknowledged.

\section{Authors' contributions}

RIS and EBS initiated and led the study; SVD, AMN, and IVM processed mtDNA samples; SVD and AMN performed mtDNA data analysis; and RIS and SVD wrote the manuscript with considerable assistance from EBS and AMN. All authors have read and approved the manuscript.

\section{Funding}

This work was supported by the Russian Science Foundation (grant number 16-14-10222 to RIS). The funders had no role in the study design, data collection, or analysis; decision to publish; or preparation of the manuscript.

\section{Availability of data and materials}

The sequence data for the new mitogenomes $(n=104)$ that support the findings of this study have been deposited in the National Center for Biotechnology Information (GenBank; http://www.ncbi.nlm.nih.gov/Genbank/ ) under accession numbers MG660751-MG660801 and MH807322-MH807374.

\section{Ethics approval and consent to participate}

Blood samples were collected from healthy unrelated adult aboriginal Siberians with appropriate informed consent (written). The protocols and the study were approved by the Ethics Committee on Animal and Human Research of the Institute of Molecular and Cellular Biology, SB RAS (protocol № 01/19, 21.01.2019), Novosibirsk, Russian Federation. All methods were carried out in accordance with the approved guidelines and regulations. The 
research was performed in accordance with the WMA Declaration of Helsinki (59th WMA General Assembly, Seoul October 2008).

\section{Consent for publication}

Not applicable.

\section{Competing interests}

The authors declare no conflicts of interest.

\section{Author details}

'Laboratory of Human Molecular Genetics, Institute of Molecular and Cellular Biology, SBRAS, Novosibirsk, Russian Federation. ${ }^{2}$ Institute of Biological Chemistry and Fundamental Medicine, SBRAS, Novosibirsk, Russian Federation. ${ }^{3}$ Novosibirsk State University, Novosibirsk, Russian Federation.

\section{Received: 2 June 2020 Accepted: 6 July 2020}

Published online: 13 July 2020

\section{References}

1. Okladnikov AP, Derevyanko AP. Dalekoye proshloye Primoriya i Priamuryia [the distant past of Primorie and Priamurie] (in Russian). Dalnevostochnoye knizhnoye izdatel'stvo: Vladivostok; 1973.

2. Okladnikov AP. The soviet Far East in antiquity an archaeological and historical study of the maritime region of the U.S.S.R. Toronto: Toronto Published for the Arctic Institute of North America by University of Toronto Press; 1965.

3. Zgusta R. The peoples of Northeast Asia through time. Precolonial ethnic and cultural processes along the coast between Hokkaido and the Bering Strait. Lam editio. Brill Academic Pub: Leiden; 2015.

4. Gibbs K, Isaksson S, Craig OE, Lucquin A, Grishchenko VA, Farrell TFG, et al, Exploring the emergence of an 'Aquatic' Neolithic in the Russian Far East: organic residue analysis of early hunter-gatherer pottery from Sakhalin Island. Antiquity. 2017;91:1484-500. https://doi.org/10.15184/aqy.2017.183.

5. Hudson MJ. The perverse realities of change: world system incorporation and the Okhotsk culture of Hokkaido. J Anthropol Archaeol. 2004:23:290-308.

6. Deryugin V. On the definition of the term "Okhotsk culture". Archaeol Ethnol Anthropol Eurasia. 2008:33:58-66.

7. Kuzmin $\mathrm{Y}$. Colonization and early human migrations in the insular Russian Far East: a view from the mid-2010s. J Is| Coast Archaeol. 2016;11:122-32.

8. Taksami CM. Tungusskiye narody na Sakhaline [Tungus people on Sakhalin] (in Russian). In: Olderogge DA, editor. editor Strani i narody Vostoka [the counties and peoples of the east], vol. VI. Moscow: Nauka; 1968. p. 29-42.

9. Boshniak NK. Zanyatie chasti ostrova Sakhalina [the occupation of a part of Sakhalin Island] (in Russian). Morskoi Sb. 1859:41:78-84.

10. Kreinovich EA. Nivkhskiy (Gilyackiy) yazik [The Nivkhi (Gilyak) Language] (in Russian). In: Yaziki i pis'mennost' narodov Severa. [Languages and Orthography of the People of the North]. Leningrad: Institut Narodov Severa; 1934. p. 181-222.

11. Vasilievski AA. Kamenniy vek ostrova Sakhalin [the stone age of Sakhalin Island]. Russian: Sakhalin State University, Institute of Archaeology and Ethnography SBRAS; 2008.

12. Vdovin IS. Ocherki etnicheskoi istorii Koryakov [an essay on ethnic history of Koryak] (in Russian). Leningrad: Nauka; 1973.

13. Krasheninnikov SP. In: Grieve J, editor. The history of Kamchatka and the Kurilski Islands, with the countries adjacent (1754). Translated by. Chicago: Quadrangle Books; 1962.

14. Jochelson W. The Koryak. Material culture and social Organization of the Koryak. A publication of the Jesop North Pacific expedition, X (2). (memoir of the American Museum of Natural History). E. J. Brill: Leiden; 1908.

15. Skorik PY. Chukotko-Kamchatkan languages. Languages of northern USSR: Mongolian, Tungusic-Manchuric and Paleoasiatic languages. (in Russian). Leningrad: Nauka; 1965.

16. Krauss ME. Many tongues - ancient tales. In: Fitzhugh W, Crowell A, editors. editors Crossroads of continents. Baltimore: Smithsonian Institution Press; 1988. p. $145-50$

17. Okladnikov AP, Vasilievsky RS. Severnaya Aziya na zare istorii. [northern Asia at the Dawn of history] (in Russian). Novosibirsk: Nauka; 1980.

18. Shternberg LI. Giliaki, orochi, gol'dy, negidal'tsy, ainy [the Gilyak, the Orochen, the gold, the Negidal, and the Ainu]. Dal'nevostochnoe knizhnoe izdatel'stvo: Khabarovsk; 1933.

19. Missonova LI. The Main spheres of activities of Sakhalin Uilta: survival experience in the present-day context; 2009.
20. Torroni A, Sukernik RI, Schurr TG, Starikovskaya YB, Cabell MF, Crawford MH, et al. mtDNA variation of Aboriginal Siberians reveals distinct genetic affinities with native Americans. Am J Hum Genet. 1993;53:591-608.

21. Starikovskaya EB, Sukernik RI, Derbeneva OA, Volodko NV, Ruiz-Pesini E, Torroni A, et al. Mitochondrial DNA diversity in indigenous populations of the southern extent of Siberia, and the origins of native American haplogroups. Ann Hum Genet. 2005;69:67-89.

22. Sukernik Rl, Volodko NV, Mazunin IO, Eltsov NP, Dryomov SV, Starikovskaya EB. Mitochondrial genome diversity in the tubalar, even, and ulchi: contribution to prehistory of native siberians and their affinities to native americans. Am J Phys Anthropol. 2012;148:123-38.

23. Schurr TG, Sukernik RI, Starikovskaya YB, Wallace DC. Mitochondrial DNA variation in Koryaks and Itel'men: population replacement in the Okhotsk Sea Bering Sea region during the Neolithic. Am J Phys Anthropol. 1999;108:1-39.

24. Mishmar D, Ruiz-Pesini E, Golik P, Macaulay V, Clark AG, Hosseini S, et al. Natural selection shaped regional mtDNA variation in humans. Proc Natl Acad Sci. 2003;100:171-6. https://doi.org/10.1073/pnas.0136972100.

25. Kong Q, Yao Y, Sun C, Zhu C. Phylogeny of east Asian mitochondrial DNA lineages inferred from complete sequences. Am J Hum Genet. 2003;73:671-6.

26. Zheng H, Yan S, Qin Z, Wang Y, Tan J, Li H, et al. Major population expansion of east Asians began before Neolithic time: evidence of mtDNA genomes. PLoS One. 2011;6:e25835.

27. Liu J, Wang L, Sun Y, Li E, Xu L, Zhang Y, et al. Deciphering the signature of selective constraints on cancerous mitochondrial genome research article. Mol Biol Evol. 2012;29:1255-61.

28. Ko AM, Chen C, Fu Q, Delfin F, Li M, Chiu H, et al. Early Austronesians: into and out of Taiwan. Am J Hum Genet. 2014:94:426-36. https://doi.org/10. 1016/j.ajhg.2014.02.003.

29. Park S, Cho S, Seo HJ, Lee JH, Kim M, Lee SD. Entire mitochondrial DNA sequencing on massively parallel sequencing for the Korean population. J Korean Med Sci. 2017;32:587-92.

30. Volodko NV, Starikovskaya EB, Mazunin IO, Eltsov NP, Naidenko PV, Wallace $D C$, et al. Mitochondrial genome diversity in Arctic Siberians, with particular reference to the evolutionary history of Beringia and Pleistocenic peopling of the Americas. Am J Hum Genet. 2008;82:1084-100.

31. Derenko M, Malyarchuk B, Grzybowski T, Denisova G, Rogalla U, Perkova M, et al. Origin and post-glacial dispersal of mitochondrial DNA haplogroups C and D in northern Asia. PLoS One. 2010;5:1-9.

32. Duggan AT, Whitten $M$, Wiebe $V$, Crawford M, Butthof A, Spitsyn $V$, et al. Investigating the prehistory of Tungusic peoples of Siberia and the AmurUssuri region with complete mtDNA genome sequences and $Y$ chromosomal markers. PLoS One. 2013:8:1-19.

33. Bermisheva MA, Kutuev IA, Spitsyn VA, Villems R, Batyrova AZ, Korshunova $\mathrm{TI}$, et al. Analysis of mitochondrial DNA variation in the population of Oroks Genetika. 2005:41:78-84.

34. Adachi N, Shinoda Kl, Umetsu K, Kitano T, Matsumura H, Fujiyama R, et al. Mitochondrial DNA analysis of Hokkaido Jomon skeletons: remnants of archaic maternal lineages at the southwestern edge of former Beringia. Am J Phys Anthropol. 2011;146:346-60.

35. Adachi N, Kakuda T, Takahashi R, Shinoda HKK Ethnic derivation of the Ainu inferred from ancient mitochondrial DNA data. Am J Phys Anthr. 2018;165:139-48.

36. Kanzawa-Kiriyama H, Saso A, Suwa G, Saitou N. Ancient mitochondrial DNA sequences of Jomon teeth samples from Sanganji, Tohoku district, Japan. Anthropol Sci. 2013;121:89-103.

37. Kanzawa-Kiriyama H, Kryukov K, Jinam TA, Hosomichi K, Saso A, Suwa G, et al. A partial nuclear genome of the Jomons who lived 3000 years ago in Fukushima, Japan. J Hum Genet. 2017;62:213-21. https://doi.org/10.1038/ jhg.2016.110.

38. Kanzawa-Kiriyama $H$, Jinam TA, Kawai Y, SATO T, Hosomichi K, Tajima A, et al. Late Jomon male and female genome sequences from the Funadomari site in Hokkaido, Japan. Anthropol Sci. 2019;127:83-108. https:// doi.org/10.1537/ase.190415.

39. Nohira C, Maruyama S, Minaguchi K. Phylogenetic classification of Japanese mtDNA assisted by complete mitochondrial DNA sequences. Int J Legal Med. 2008;124:7. https://doi.org/10.1007/s00414-008-0308-5.2.

40. Sikora M, Pitulko W, Sousa VC, Allentoft ME, Vinner L, Rasmussen S, et al. The population history of northeastern Siberia since the Pleistocene. Nature. 2019. https://doi.org/10.1038/s41586-019-1279-z.

41. Sukernik RI, Volodko NV, Mazunin IO, Eltsov NP, Starikovskaya EB. The genetic history of Russian old settlers of polar northeastern Siberia. Russ J Genet. 2010;46:1386-94. https://doi.org/10.1134/S1022795410110153. 
42. Dryomov SV, Nazhmidenova AM, Shalaurova SA, Morozov IV, Tabarev AV, Starikovskaya EB, et al. Mitochondrial genome diversity at the Bering Strait area highlights prehistoric human migrations from Siberia to northern North America. Eur J Hum Genet. 2015;23:1399-404.

43. Siska V, Jones ER, Jeon S, Bhak Y, Kim HM, Cho YS, et al. Genome-wide data from two early Neolithic east Asian individuals dating to 7700 years ago. Sci Adv. 2017;3:e1601877.

44. Wang C-C, Yeh H-Y, Popov AN, Zhang H-Q, Matsumura H, Sirak K, et al. The Genomic Formation of Human Populations in East Asia. bioRxiv. 2020; 2020. 03.25.004606. https://doi.org/10.1101/2020.03.25.004606.

45. Li H, Durbin R. Fast and accurate long-read alignment with burrowswheeler transform. Bioinformatics. 2010;26:589-95.

46. Okonechnikov K, Golosova O, Fursov M, Varlamov A, Vaskin Y, Efremov I, et al. Unipro UGENE: a unified bioinformatics toolkit. Bioinformatics. 2012;28:1166-7.

47. mtPhyl - software tool for human mtDNA analysis and phylogeny reconstruction. https://eltsov.org/mtphyl. Accessed 13 Nov 2019.

48. Behar DM, Van Oven M, Rosset S, Metspalu M, Loogväli EL, Silva NM, et al. A "copernican" reassessment of the human mitochondrial DNA tree from its root. Am J Hum Genet. 2012;90:675-84.

49. van Oven M, Kayser M. Updated comprehensive phylogenetic tree of global human mitochondrial DNA variation. Hum Mutat. 2009;30:386-94.

50. Drummond AJ, Rambaut A. BEAST: Bayesian evolutionary analysis by sampling trees. BMC Evol Biol. 2007;7:1-8.

51. Fu Q, Mittnik A, Johnson PLF, Bos K, Lari M, Bollongino R, et al. A revised timescale for human evolution based on ancient mitochondrial genomes. Curr Biol. 2013:23:553-9.

52. Darriba D, Taboada GL, Doallo R, Posada D. jModelTest 2: more models, new heuristics and parallel computing. Nat Methods. 2012;9:772.

\section{Publisher's Note}

Springer Nature remains neutral with regard to jurisdictional claims in published maps and institutional affiliations.

Ready to submit your research? Choose BMC and benefit from:

- fast, convenient online submission

- thorough peer review by experienced researchers in your field

- rapid publication on acceptance

- support for research data, including large and complex data types

- gold Open Access which fosters wider collaboration and increased citations

- maximum visibility for your research: over $100 \mathrm{M}$ website views per year

At $\mathrm{BMC}$, research is always in progress.

Learn more biomedcentral.com/submissions 